\title{
Partitioning coefficient-A trait that contributes to drought tolerance in chickpea
}

\author{
L. Krishnamurthy ${ }^{\mathrm{a}, *}$, J. Kashiwagi ${ }^{\mathrm{b}}$, H.D. Upadhyaya ${ }^{\mathrm{a}}$, C.L.L. Gowda ${ }^{\mathrm{a}}$, P.M. Gaur ${ }^{\mathrm{a}}$, \\ Sube Singh a , R. Purushothaman ${ }^{a}$, R.K. Varshney ${ }^{\mathrm{a}}$ \\ a International Crops Research Institute for the Semi-Arid Tropics (ICRISAT), Patancheru 502 324, Andhra Pradesh, India \\ b Crop Science Lab, Graduate School of Agriculture, Hokkaido University, Kita 9 Nishi 9, Kita-Ku, Sapporo, 060-8589, Japan
}

\section{A R T I C L E I N F O}

\section{Article history:}

Received 7 March 2013

Received in revised form 24 May 2013

Accepted 24 May 2013

\section{Keywords:}

Crop growth rate

Drought stress

Genetic variability

Harvest index

Path coefficient analysis

Rate of partitioning

\begin{abstract}
A B S T R A C T
Chickpea is increasingly being grown in tropical areas, and terminal drought is becoming a major constraint to its increased productivity. A trait-based selection approach can achieve further gains in drought tolerance that has been achieved through direct selection for yield. Separation of yield into its components including the rate of partitioning and its duration could permit a better focus on the most relevant trait for yield enhancement under terminal drought. Current work is aimed at understanding the importance of rate of partitioning or the partitioning coefficient $(p)$ as a major contributory trait associated with drought tolerance both in germplasm and breeding lines. A reference collection of chickpea germplasm $(n=280)$ was evaluated in the field under both terminal drought and optimally irrigated environments; and a set of desi $(n=60)$ and kabuli $(n=60)$ advanced breeding lines under terminal drought. Grain yield was associated with its analytical components - crop growth rate $(C)$, reproductive duration (Dr) and $p$. The path analysis showed that $C$ and $p$ had a large direct positive contribution to yield while $\mathrm{Dr}$ had a marginal but negative contribution to yield under drought. The direct contribution of $p$ was the highest but it was marginally reduced by the indirect negative contributions of Dr. However, the total contributions of $p$ to grain yield remained large. The yield of germplasm accessions under drought across the seasons were closely associated $\left(r^{2}=0.70\right)$ and also the genotype $\times$ year interaction was minimum. The contribution of $C$, Dr and $p$ to grain yield were similar in the advanced breeding lines. However, kabuli breeding lines had a larger variation for $p$ than the desi lines. The results suggest that a conscious selection for greater $p$ will confer greater tolerance to abiotic stresses, given that terminal drought tends to curtail the length of the reproductive period.
\end{abstract}

(C) 2013 Elsevier B.V. All rights reserved.

\section{Introduction}

Chickpea (Cicer arietinum L.), the second most important grain legume crop in the world, is widely grown across the Mediterranean basin, East Africa, Indian-subcontinent, Americas and Australia (FAO, 2012). Ninety percent of world's chickpea is grown rainfed (Kumar and Abbo, 2001) where terminal drought is one of the major constraints limiting productivity. In 2050, global demand for chickpea is projected to be $18.3 \mathrm{Mt}$ (2010 supply is $9.4 \mathrm{Mt}$ ), and the low income food deficit countries are expected to suffer the widest supply-demand gap (Nedumaran and Bantilan, 2013). Most of this deficit can be met through breeding for drought tolerance and yield stability. A physiological trait-based breeding approach is proposed to have merit over breeding for yield per se as it increases

\footnotetext{
* Corresponding author. Tel.: +91 40 30713657; fax: +91 4030713074 . E-mail addresses: 1.krishnamurthy@cgiar.org, LKM1949@gmail.com (L. Krishnamurthy).
}

the probability of crosses resulting in additive gene action (Ludlow and Muchow, 1990; Reynolds and Trethowan, 2007; Wasson et al., 2012). Growth rates and productivity under water limited conditions can be improved only when most relevant drought tolerance traits are identified and brought under a single genetic background.

Analytically, grain yield (YLD) under drought environments can be explained by the following equation (Passioura, 1977; Fischer, 1981):

$$
\text { grain yield }=\operatorname{transpiration}(T) \times \text { transpiration efficiency }(T E)
$$$$
\times \text { harvest index }(H I)
$$

This suggests that improvement of any one component (or combination) of yield is expected to improve the grain yield under drought environments. Improvement of HI (see formula), is considered to be relatively less cumbersome and was deferred to be dealt with at the last stages of breeding and selection. Hence, improvement for the components $T$ (Kashiwagi et al., 2005) and TE 
(Kashiwagi et al., 2006b) have been given a higher priority as they can increase the total shoot biomass. Breeding efforts for improved $T$ and TE, by introgressing associated QTLs into ruling varieties (Varshney et al., 2009), had been shown to ensure large additional yield advantages at research station level (Gaur et al., 2013). Thus, to understand the extent of variation for this yield component, it becomes necessary to explore and exploit the variation for $\mathrm{HI}$ in the germplasm.

High heritability of HI coupled with the weak response to environmental variation (Hay, 1995) makes it suitable as a major trait for improving yield stability under stress. However, HI alone had not been considered as a yield determining trait for selection as high yields under drought were the product of interaction of growth rates and HI. Therefore, success in selecting for high yield under drought requires a simultaneous selection for both crop growth rates and $\mathrm{HI}$. An independent selection for $\mathrm{HI}$ alone poses the danger of selecting entries with a poor biomass potential (Wallace et al., 1993).

In another analytical model of yield determination, HI was considered as a product of two components; i.e. the reproductive duration and the $p$ to grains (Duncan et al., 1978; Williams and Saxena, 1991; Gallagher et al., 1976; Scully and Wallace, 1990; Krishnamurthy et al., 1999). Terminal stress in chickpea, as in many other crops, is known to reduce the growth duration, especially the reproductive phase. Therefore, it can be envisaged that since there is a ceiling to the reproductive growth duration due to ever increasing drought and heat stress at the final stages of reproductive growth, it would be worth aiming to increase $p$, thereby allowing the plants to escape the later stress stages without compromising the yield formation. Several plant functions such as increased radiation use efficiency, non-lodging crop stands, increased sink size (twin pods in each node or smaller leaf size), more terminal branches, synchrony in flowering and greater flower production per unit area can be envisaged as contributing to increased $p$.

Characterization of germplasm for various traits was made manageable with the development of a reference collection of chickpea germplasm, representing the molecular diversity of a global composite collection (3000 accessions at 50 microsatellite loci) (Upadhyaya et al., 2006). This reference collection also exhibits enormous diversity for tolerance to high temperature (Krishnamurthy et al., 2011a), soil salinity (Krishnamurthy et al., 2011b) and terminal drought. Therefore, the objective of this study was to (i) explore the biological diversity in the analytical yield components; (ii) identify the trait(s) that associate closely with yield both under drought-stressed and optimallyirrigated environments; and (iii) identify contrasting germplasm accessions for the most useful traits from the reference collection.

\section{Materials and methods}

\subsection{Crop management of germplasm evaluation}

The cultivated accessions of the chickpea germplasm $(n=280)$ reference collection (Upadhyaya et al., 2008) were evaluated under field conditions during the postrainy seasons of 2008-2009 and 2009-2010 on Vertisol (fine montmorillonitic isohyperthermic typic pallustert) at ICRISAT - Patancheru $\left(17^{\circ} 30^{\prime} \mathrm{N} ; 78^{\circ} 16^{\prime}\right.$ $\mathrm{E}$; altitude $549 \mathrm{~m})$, in peninsular India. The soil depth of the fields used in 2008-2009 was $\geq 1.2 \mathrm{~m}$, and $1.1 \mathrm{~m}$ in $2009-2010$. These soils retained about $230 \mathrm{~mm}(2008-2009)$ and $205 \mathrm{~mm}$ (2009-2010) of plant-available water in the 120-cm (maximum rooting depth) soil profile. The fields were solarized using polythene mulch during the preceding summer to eradicate wilt causing fungi Fusarium oxysporum f. sp. ciceris (Chauhan et al., 1988). The field was kept fallow and Glyphosate (Roundup ${ }^{\circledR}$ ) herbicide was applied prior to land preparation only during 2008-2009.

The fields were prepared into $1.2 \mathrm{~m}$ wide broad beds flanked by $0.3 \mathrm{~m}$ furrows for all the experiments. Surface application and incorporation of $18 \mathrm{~kg} \mathrm{Nha}^{-1}$ and $20 \mathrm{~kg} \mathrm{Pha}^{-1}$ as di-ammonium phosphate was carried out in all the experiments. The plot consisted of 2 rows of $4 \mathrm{~m}$ length in both the seasons. The experiments were conducted with two irrigation levels - drought stressed: nonirrigated except for a post-sowing irrigation; and irrigated: optimally irrigated depending on the need with three replications. Seeds were treated with $0.5 \%$ Benlate $^{\circledR}$ (E.I. DuPont India Ltd., Gurgaon, India $)+$ Thiram $^{\circledR}$ (Sudhama Chemicals Pvt. Ltd., Gujarat, India) mixture in both seasons. Both the experiments were hand planted at the first opportunity after the cessation of the rains on 31 Oct 2008 and 31 Oct 2009 in rows $30 \mathrm{~cm}$ apart with $10 \mathrm{~cm}$ between plants at $3-5 \mathrm{~cm}$ depth with two seeds per hill, later thinned to one. During both the seasons, the fields were inoculated with Rhizobium strain IC 59 using the liquid inoculation method. A $50 \mathrm{~mm}$ irrigation through perforated pipes was applied the next day to ensure complete emergence. Successive irrigations, to the irrigated treatments were through furrow irrigation. Intensive protection against pod borer (Helicoverpa armigera) was provided and the plots were kept weed free by manual weeding.

\subsection{Crop management of advanced yield trials}

There were six experiments each with twenty entries. These were three sets of $\mathrm{F}_{4}$ progenies each from desi and kabuli, derived from desi $\times$ desi and a kabuli $\times$ kabuli crosses that were made to further enhance the early growth vigor and yield performance of existing released varieties. The desi varieties intended for improvement were ICCV 10, ICCC 37, JG 11 and ICCV 96021; the kabuli were KAK 2, JGK 1, ICCV 2 and ICCV 95311. These entries were evaluated rainfed in Vertisol field at ICRISAT in 2009-2010. The soil depth of the field was $\geq 1.5 \mathrm{~m}$ and these soils retained about $230 \mathrm{~mm}$ of plant-available water in the $120 \mathrm{~cm}$ (maximum rooting depth) soil profile. These fields were kept fallow during other seasons.

The broad bed and furrow system, basal fertilizers and the seed dressing were the same for the germplasm evaluation. The plot size was $4.0 \mathrm{~m} \times 4 \mathrm{~m}$ rows in all the six experiments which were conducted purely rainfed with four replications. These experiments were sown with a 4-cone planter on 29 October 2010 in rows $30 \mathrm{~cm}$ apart at a depth of $3-5 \mathrm{~cm}$ to have an estimated plant stand of at least 27 plants $\mathrm{m}^{-2}$. Intensive protection against pod borer ( $H$. armigera) was provided, and the plots were kept weed free by manual weeding.

The date when $50 \%$ or more of the plants had flowered was recorded as $50 \%$ flowering time of the plot, when $50 \%$ or more of the plants had produced one pod at least was recorded as $50 \%$ podding time of the plot, when $80 \%$ or more pods were yellow was recorded as physiological maturity and when $80 \%$ of the pods in a plot were dried was recorded as the time of maturity for each plot.

\subsection{Soil moisture measurements}

In both years, neutron moisture meter access tubes were installed in four spots planted with two drought tolerant (ICC 867 and ICC 14778) and two drought sensitive accessions (ICC 6263 and ICC 8058) (Krishnamurthy et al., 2010) in an adjacent broad bed in each replication and treatment. Neutron moisture meter (Depth Moisture Gauge, Model 3332, Troxler Electronic Laboratories Inc., NC, USA) readings at soil depths of $15 \mathrm{~cm}$ increments up to a depth of $120 \mathrm{~cm}$ were made before and after each 
irrigation as well as matching it at about 10 day intervals. The troxler soil moisture observations were corrected with a calibration curve developed for each depth separately using the data collected gravimetrically across the season. Moisture content of the surface soil $(0-15 \mathrm{~cm})$ was measured only gravimetrically. The water held in each soil horizon of $15 \mathrm{~cm}$ depth was summed up to $1.2 \mathrm{~m}$.

\subsection{Final harvest}

At maturity, plant aerial parts were harvested at ground level from an area of $2.7 \mathrm{~m}^{2}(3.6 \times 0.75 \mathrm{~m})$ in the germplasm evaluation and $5.4 \mathrm{~m}^{2}(3.6 \times 1.5 \mathrm{~m})$ in the advanced yield trials with care to eliminate border effects in each plot, dried to constant weight in hot air dryers at $45^{\circ} \mathrm{C}$, and total shoot dry weights were recorded. Grain weights were recorded after threshing. For each chickpea line, the time taken for pre-podding and post-podding periods was converted to thermal time using temperature observations in the meteorological observatory of ICRISAT - Patancheru. Base temperature $\left(t_{\mathrm{b}}\right)$ was taken as $0^{\circ} \mathrm{C}$ (Williams and Saxena, 1991; Singh and Virmani, 1996) and the equation used for calculating thermal time $\left({ }^{\circ} \mathrm{Cd}\right)$ was:

$$
{ }^{\circ} \mathrm{Cd}=\sum_{t=0}^{n}\left(\frac{t_{\mathrm{max}}+t_{\mathrm{min}}}{2}-t_{\mathrm{b}}\right)
$$

The crop growth rate $(C)$ in $\mathrm{kg} \mathrm{ha}^{-1}{ }^{\circ} \mathrm{Cd}$ and partitioning coefficient of each line were estimated using the equations:

$C=\frac{V+Y}{\mathrm{Dv}+\mathrm{Dr}} \quad$ and $\quad p=\frac{Y / \mathrm{Dr}}{C}$

where $V=$ vegetative shoot mass $\mathrm{kg} \mathrm{ha}^{-1}$ (adjusted for leaf fall); $Y=$ grain mass $\mathrm{kg} \mathrm{ha}^{-1} ; \mathrm{Dr}=$ duration of growth after the start of $50 \%$ podding ${ }^{\circ} \mathrm{Cd}$; $\mathrm{Dv}=$ duration of growth before the start of $50 \%$ podding ${ }^{\circ} \mathrm{Cd}$.

\subsection{Statistical analysis}

The replication-wise values of yield and yield components were used for statistical analysis of each environment using ReML considering genotypes as random. Variance components due to genotypes $\left(\sigma_{\mathrm{g}}^{2}\right)$ and error $\left(\sigma_{\mathrm{e}}^{2}\right)$ and their standard errors were determined. Environment-wise best linear unbiased predictors (BLUPs) for the germplasm accessions and the advanced generation progenies were calculated. Heritability was broadly estimated as $h^{2}=$ $\sigma_{\mathrm{g}}^{2}\left(\sigma_{\mathrm{g}}^{2}+\sigma_{\mathrm{e}}^{2}\right)$. The significance of genetic variability among accessions was assessed from the standard error of the estimate of genetic variance $\sigma_{\mathrm{g}}^{2}$, assuming the ratio $\sigma_{\mathrm{g}}^{2} /$ S.E. $\left(\sigma_{\mathrm{g}}^{2}\right)$ to follow normal distribution asymptotically.

For the pooled analysis, homogeneity of variance was tested using Bartlett's test (Bartlett, 1937). Here, the year (environment) was treated as a fixed effect and the genotype as random. The variance due to $(G) \sigma_{\mathrm{g}}^{2}$ and $(G) \times(E)$ interaction $\left(\sigma_{\mathrm{gE}}^{2}\right)$ and their standard error were determined. The significance of the fixed effect of the year was assessed using the Wald statistic that asymptotically follows a $\chi^{2}$ distribution.

Regression and the path analyses were performed using the individual year and BLUPs under both irrigation levels. Path analysis in this case was sought to separate the correlations into different components of direct and indirect effects due to a large number of independent variables that are expected to contribute to the dependant variable, the grain yield.

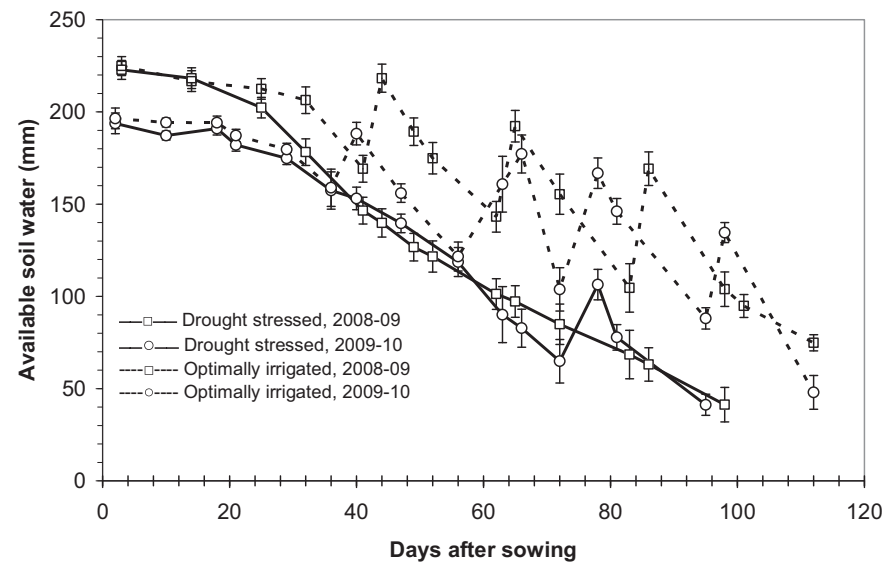

Fig. 1. Changes in available soil moisture up to a soil depth of $1.2 \mathrm{~m}$ across the crop growing seasons of 2008-2009 and 2009-2010. Vertical bars denote standard error of differences $( \pm)$.

\section{Results}

\subsection{Extent of terminal drought}

In both the years, the rain received prior to the cropping season was $>850 \mathrm{~mm}$, well distributed ensuring complete charging of the soil profile. Rains totaling $26 \mathrm{~mm}$ for $15-30$ days after sowing in 2008-2009 and $44 \mathrm{~mm}$ for 9-19 days after sowing in 2009-2010 delayed the onset of drought, but the drought stressed crop suffered terminal drought (data not shown). There was another rain $(39 \mathrm{~mm})$ at 75 days after sowing during 2009-2010, but the early maturing accessions under drought stress had crossed the stage of response and most late maturing accessions under optimum irrigation suffered excessive vegetative growth and lodging due to this rain. Overall, the minimum temperatures were higher, particularly during the critical third and fourth week of December (flowering and early-podding season for the adapted germplasm), and maximum temperatures were lower during 2009-2010 (Table 1). The daily evaporation normally around $3-4 \mathrm{~mm}$ increased to 5 and beyond after 82 days of sowing in 2008-2009, and 91 days in 2009-2010, which reflected in the cumulative evaporation presented in Table 1.

Broadly, the pattern of soil moisture depletion did not vary between the two seasons under drought stress except that the season started with greater available soil moisture in 2008-2009, and this difference was maintained till 30 days after sowing (Fig. 1). The available water in the soil profile was the lowest in 2009-2010 under drought stress between 60 and 70 days after sowing. At maturity under drought stress the available soil water left unutilized was about the same in both seasons and less than $50 \mathrm{~mm}$. Irrigations at the early stages of the season raised the total available soil water to initial levels, whereas as the season advanced irrigations did not fully charge the profile. It was likely due to the poor rate of percolation in Vertisols compared to slow rate by rains, and it was found that the top $60 \mathrm{~cm}$ soil only got wet when irrigation was turned off at the beginning of runoff (Fig. 1).

\subsection{Extent of variation among chickpea germplasm accessions}

The increase in mean shoot dry matter and grain yield with irrigation was about 50\% (Table 2). The germplasm accessions varied two-fold in shoot biomass production and many-fold in grain yield. Compared to the irrigated condition, durations of both the vegetative (Dv) and reproductive (Dr) phases of growth were reduced by drought stress, but these reductions were large for the reproductive phase compared to the vegetative phase (Fig. 2 ). The 
Table 1

Summary of the weather during the vegetative and reproductive phases of the three cropping seasons.

\begin{tabular}{|c|c|c|c|c|c|}
\hline \multirow[t]{2}{*}{ Year/period } & \multirow[t]{2}{*}{ Total rainfall $(\mathrm{mm})$} & \multicolumn{2}{|c|}{ Mean temperature $\left({ }^{\circ} \mathrm{C}\right)$} & \multirow[t]{2}{*}{ Mean maximum VPD $(\mathrm{kPa})$} & \multirow[t]{2}{*}{ Total evaporation (mm) } \\
\hline & & Max & Min & & \\
\hline \multicolumn{6}{|l|}{$2008-2009$} \\
\hline Early Dv & 25.5 & 29.8 & 15.9 & 2.33 & 111.4 \\
\hline Late Dv & 1.1 & 29.4 & 13.4 & 2.43 & 98.6 \\
\hline Early Dr & 0.0 & 28.3 & 13.4 & 2.25 & 81.2 \\
\hline Late $\mathrm{Dr}$ & 0.0 & 32.1 & 13.4 & 3.52 & 106.2 \\
\hline \multicolumn{6}{|l|}{ 2009-2010 } \\
\hline Early Dv & 44.2 & 29.5 & 19.0 & 1.97 & 110.4 \\
\hline Late Dv & 0.0 & 28.2 & 13.4 & 2.24 & 103.9 \\
\hline Early Dr & 46.4 & 27.5 & 15.1 & 1.91 & 67.0 \\
\hline Late $\mathrm{Dr}$ & 0.0 & 27.9 & 13.5 & 2.29 & 81.0 \\
\hline \multicolumn{6}{|l|}{ 2010-2011 } \\
\hline Early Dv & 12.5 & 28.3 & 17.7 & 1.73 & 75.8 \\
\hline Late Dv & 0.0 & 27.3 & 11.3 & 2.14 & 77.9 \\
\hline Early Dr & 0.0 & 29.2 & 10.6 & 2.67 & 136.5 \\
\hline Late $\mathrm{Dr}$ & 0.4 & 31.2 & 16.2 & 2.95 & 163.1 \\
\hline
\end{tabular}

Table 2

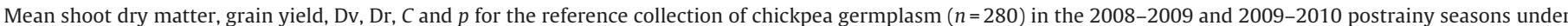
drought stressed and optimally irrigated conditions.

\begin{tabular}{|c|c|c|c|c|c|}
\hline Season/environment & Trial mean & Range of predicted means & S.E. & $\sigma_{\mathrm{g}}^{2}$ (S.E.) & Heritability $\left(h^{2}\right)$ \\
\hline \multicolumn{6}{|l|}{ 2008-2009 } \\
\hline \multicolumn{6}{|l|}{ Drought stressed } \\
\hline Shoot dry matter $\left(\mathrm{kg} \mathrm{ha}^{-1}\right)$ & 3444 & $2559-4726$ & 380.9 & $220,188(28,546)$ & 0.671 \\
\hline Grain yield $\left(\mathrm{kg} \mathrm{ha}^{-1}\right)$ & 1557 & $510-2250$ & 205.3 & $91,544(10,202)$ & 0.770 \\
\hline $\mathrm{Dv}\left({ }^{\circ} \mathrm{Cd}\right)$ & 1286 & $1033-1700$ & 33.0 & $15,155(1331)$ & 0.964 \\
\hline $\operatorname{Dr}\left({ }^{\circ} \mathrm{Cd}\right)$ & 878 & 759-1161 & 41.7 & $3482(399)$ & 0.751 \\
\hline$C\left(\mathrm{~kg} \mathrm{ha}^{-1}{ }^{\circ} \mathrm{Cd}^{-1}\right)$ & 1.93 & $1.23-2.57$ & 0.210 & $0.0630(0.0084)$ & 0.652 \\
\hline$p$ & 0.93 & $0.22-1.20$ & 0.069 & $0.0312(0.0029)$ & 0.923 \\
\hline \multicolumn{6}{|l|}{ Optimally irrigated } \\
\hline Shoot dry matter $\left(\mathrm{kg} \mathrm{ha}^{-1}\right)$ & 5263 & $3602-6977$ & 576.5 & $447,678(62,609)$ & 0.629 \\
\hline Grain yield $\left(\mathrm{kg} \mathrm{ha}^{-1}\right)$ & 2057 & 1004-3029 & 270.7 & $138,923(16,309)$ & 0.737 \\
\hline $\mathrm{Dv}\left({ }^{\circ} \mathrm{Cd}\right)$ & 1354 & 1067-1666 & 42.9 & $18,458(1649)$ & 0.950 \\
\hline $\operatorname{Dr}\left({ }^{\circ} \mathrm{Cd}\right)$ & 1231 & 1026-1512 & 51.3 & $7024(741.0)$ & 0.812 \\
\hline$C\left(\mathrm{~kg} \mathrm{ha}^{-1}{ }^{\circ} \mathrm{Cd}^{-1}\right)$ & 2.46 & $1.69-3.15$ & 0.265 & $0.089(0.013)$ & 0.607 \\
\hline$p$ & 0.69 & $0.35-0.97$ & 0.061 & $0.013(0.0013)$ & 0.861 \\
\hline \multicolumn{6}{|l|}{$2009-2010$} \\
\hline \multicolumn{6}{|l|}{ Drought stressed } \\
\hline Shoot dry matter $\left(\mathrm{kg} \mathrm{ha}^{-1}\right)$ & 4120 & 2822-5499 & 430.9 & $303,086(37,854)$ & 0.694 \\
\hline Grain yield $\left(\mathrm{kg} \mathrm{ha}^{-1}\right)$ & 1518 & $442-2314$ & 209.3 & $134,255(13,672)$ & 0.837 \\
\hline $\mathrm{Dv}\left({ }^{\circ} \mathrm{Cd}\right)$ & 1245 & $959-1610$ & 41.5 & $16,271(1456)$ & 0.947 \\
\hline $\operatorname{Dr}\left({ }^{\circ} \mathrm{Cd}\right)$ & 847 & $679-1102$ & 68.8 & $9480(1086)$ & 0.750 \\
\hline$C\left(\mathrm{kgha}^{-1}{ }^{\circ} \mathrm{Cd}^{-1}\right)$ & 2.40 & $1.55-3.17$ & 0.245 & $0.089(0.012)$ & 0.663 \\
\hline$p$ & 0.78 & $0.22-1.25$ & 0.075 & $0.060(0.0053)$ & 0.953 \\
\hline \multicolumn{6}{|l|}{ Optimally irrigated } \\
\hline Shoot dry matter $\left(\mathrm{kg} \mathrm{ha}^{-1}\right)$ & 6781 & $3566-8926$ & 773.1 & $1,086,034(129,247)$ & 0.725 \\
\hline Grain yield $\left(\mathrm{kg} \mathrm{ha}^{-1}\right)$ & 1522 & 694-2311 & 302.8 & $136,055(17,861)$ & 0.663 \\
\hline $\mathrm{Dv}\left({ }^{\circ} \mathrm{Cd}\right)$ & 1331 & $981-1583$ & 63.4 & $17,458(1678)$ & 0.885 \\
\hline $\operatorname{Dr}\left({ }^{\circ} \mathrm{Cd}\right)$ & 1161 & $990-1475$ & 67.5 & $10,641(1159)$ & 0.786 \\
\hline$C\left(\mathrm{~kg} \mathrm{ha}^{-1}{ }^{\circ} \mathrm{Cd}^{-1}\right)$ & 3.29 & $1.79-4.26$ & 0.374 & $0.228(0.028)$ & 0.693 \\
\hline$p$ & 0.40 & $0.22-0.63$ & 0.066 & $0.009(0.0010)$ & 0.744 \\
\hline
\end{tabular}

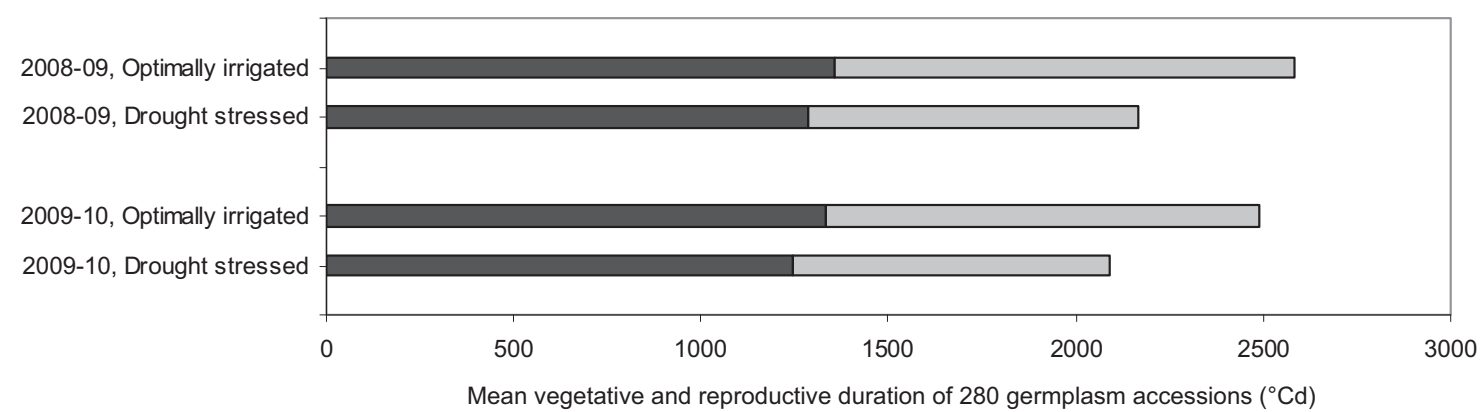

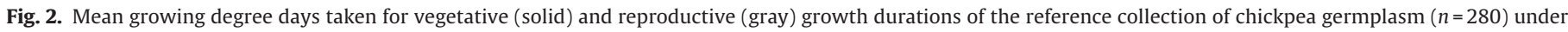
both optimally irrigated and drought stressed conditions during two years (2008-2009 and 2009-2010). 
Table 3

Interaction of genotype with year for the grain yield and its analytical components $C$, Dr and $p$ in the reference collection of chickpea germplasm $(n=280)$ during 2008-2009 and 2009-2010 postrainy seasons under drought stressed and optimally irrigated conditions.

\begin{tabular}{lll}
\hline & \multicolumn{2}{l}{ Variance component (S.E.) } \\
\cline { 2 - 3 } & Drought stressed & Optimally irrigated \\
\hline $\begin{array}{l}\text { Grain yield }\left(\mathrm{kg} \mathrm{ha}^{-1}\right) \\
\quad \text { Genotype }\end{array}$ & $90,306(9958)$ & $109,340(13,522)$ \\
$\quad$ Genotype $\times$ year & $21,598(4342)$ & $26,251(7913)$ \\
$\quad \quad$ Genotype & $0.0652(0.0079)$ & $0.1251(0.0161)$ \\
$\quad$ Genotype $\times$ year & $0.0096(0.0046)$ & $0.0335(0.0102)$ \\
Dr Genotype & $3833(566)$ & $7173(791)$ \\
$\quad$ Genotype $\times$ year & $2589(417)$ & $1633(346)$ \\
$p \quad$ Genotype & $0.0372(0.0037)$ & $0.0088(0.0009)$ \\
$\quad$ Genotype $\times$ year & $0.0083(0.0009)$ & $0.0020(0.0004)$ \\
\hline
\end{tabular}

decrease in Dv was 5 and 6\% in 2008-2009 and 2009-2010 and in Dr was 29 and 27\%. The differences in mean Dv between the drought stressed and the irrigated treatments were low as the difference in soil moisture between the irrigation treatments at this stage was expected to be low. $C$ was substantially increased by irrigation but $p$ was substantially reduced during 2009-2010 (Table 2). The heritability of shoot biomass was moderate and was between 0.63 and 0.73 . The heritability of grain yield $(0.66$ and 0.84$)$ under drought stress was relatively high compared to the shoot biomass. The heritability of the vegetative duration was high, while that of the reproductive duration was moderately high. Among the yield components the heritability of $p$ under drought stress was the highest (0.92 and 0.95) (Table 2).

The pooled analysis of variation with both the years showed that the genotype $\times$ year effect was significant for the grain yield and all the other components of yield. However the extent of genotypic variance was 4-5 times greater than the genotype $\times$ year interaction component except for Dr in 2008-2009 (Table 3).

\subsection{The relationship between yield and model parameters $(C, D r$ and $p$ ) of the germplasm accessions}

The mean yields of accessions under both soil moisture levels in the two seasons were considered together for a regression analysis of yield with $C$, Dr and $p, 84.5 \%$ of variation was explained by this analytical model (data not shown). When the germplasm accessions $\times$ year variations were considered individually for both drought stressed and optimally irrigated environments, $>94 \%$ of the variation, in each case was explained - demonstrating the efficiency of the model in explaining the yield variation.

The regression between yield and $C$ was positive and explained 55 and $19 \%$ of the yield variation in the two years under drought stressed conditions, and 36 and $16 \%$ under optimally irrigated conditions (Fig. 3). The path coefficients also showed large positive direct association of $C$ that changed only slightly due to indirect contributions through $\mathrm{Dr}$ and $p$. Such a direct or total contribution by $C$ was greater under drought stressed conditions, compared to the irrigated conditions (Table 4). Dr regressed negative with grain yield explaining large variation under drought stressed condition while it was not related under irrigated conditions (Fig. 4). Direct path coefficients of Dr were always positive irrespective of irrigation treatments that became more negative due to heavy indirect negative contribution through $p$. Such negative indirect contribution through $p$ was minimal under irrigated conditions leading to a positive total contribution.

The regression between yield and $p$ was positive explaining 68 and $47 \%$ of the yield variation in the two years under
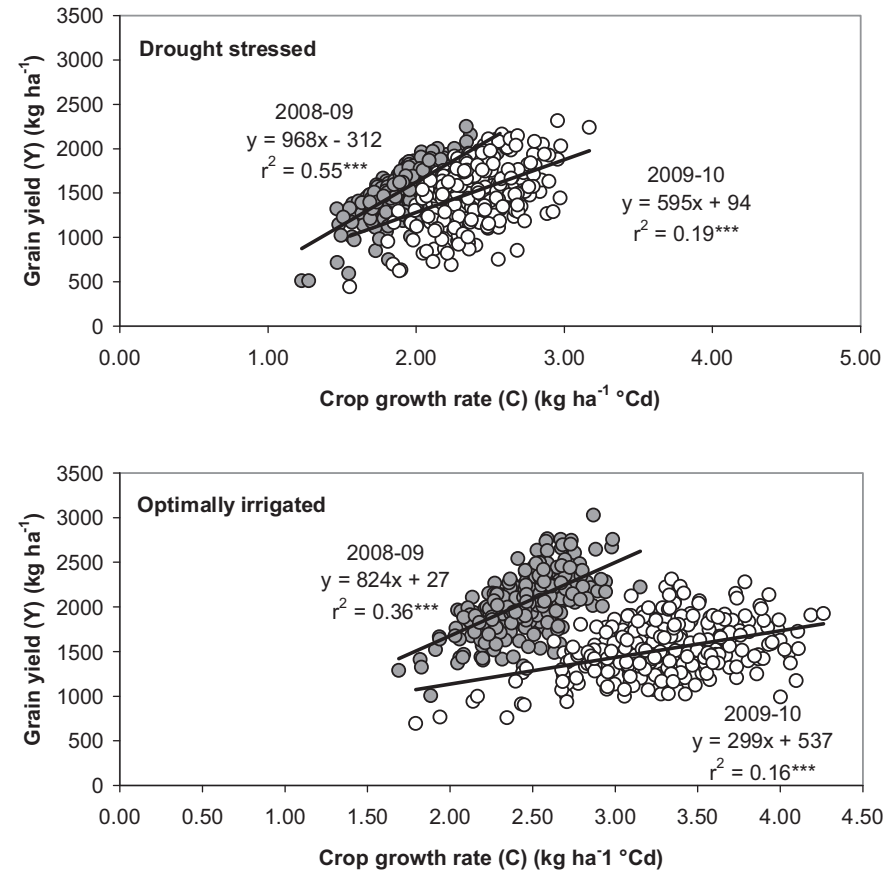

Fig. 3. The relationship between crop growth rate and the grain yield of the reference collection of chickpea germplasm $(n=280)$ in the two years $(2008-2009=$ solid dots and 2009-2010=open dots) both under drought stressed and optimally irrigated conditions.

drought stressed conditions, and 64 and 34\% of the yield variation under optimally irrigated conditions (Fig. 5). The path coefficients also showed large positive direct contribution by $p$ that changed marginally due to primary indirect contribution through Dr. Such direct or total contribution by $p$ was greater under drought stressed condition compared to the irrigated condition (Table 4).

\subsection{Extent of variation among advanced chickpea breeding lines}

All the means of the chickpea breeding lines for shoot biomass and grain yield was high for a rain-fed drought stressed crop (Table 5). Yields were high due to advantages in this crop's favor, such as early planting, fallow season, two rainfalls during the early growing season and less soil compaction. The shoot biomass production and grain yield variation among the breeding lines of desi trials were not significant except for the grain yield in desi trial 2 while significant at $5 \%$ level in the three kabuli trials. The range in shoot biomass productivity or grain yield was also narrow within each of these six trials. The desi trials had marginally higher biomass (4.8-5.1 t) productivity than the kabuli trials (4.5-4.9 $\mathrm{t}$ ). The mean grain yield of desi trials were close to $2.8 \mathrm{t}$ whereas it was $2.2 \mathrm{t}$ in the kabuli trials. The range of $C$ was $2.4-2.9$ in the desi trials, and $2.2-2.6 \mathrm{~kg} \mathrm{ha}^{-1}{ }^{\circ} \mathrm{Cd}$ in the kabuli trials. Dr was $999-1191^{\circ} \mathrm{Cd}$ in the desi trials and 1070-1412 in the kabuli trials. The $p$ ranged between 0.8 and 1.1 with a mean of 1.0 in the desi, whereas the mean was near 0.75 in the kabulis. The heritability of Dv, Dr and $p$ was close to 0.9 in all the six trials whereas it was $0.5-0.8$ for the shoot biomass, grain yield and the $C$ (Table 5 ).

\subsection{Relationship between yield and model parameters in the breeding lines}

The regression between yield and $C$ was positive. It was close in the three desi trials and explained 56, 66 and $45 \%$ of the yield variation, and not that close in the kabuli trials, explaining 16 , 
Table 4

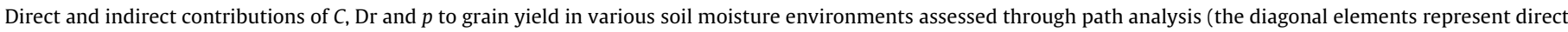
effects, and the off-diagonal elements the indirect effects; the total represents the net effects).

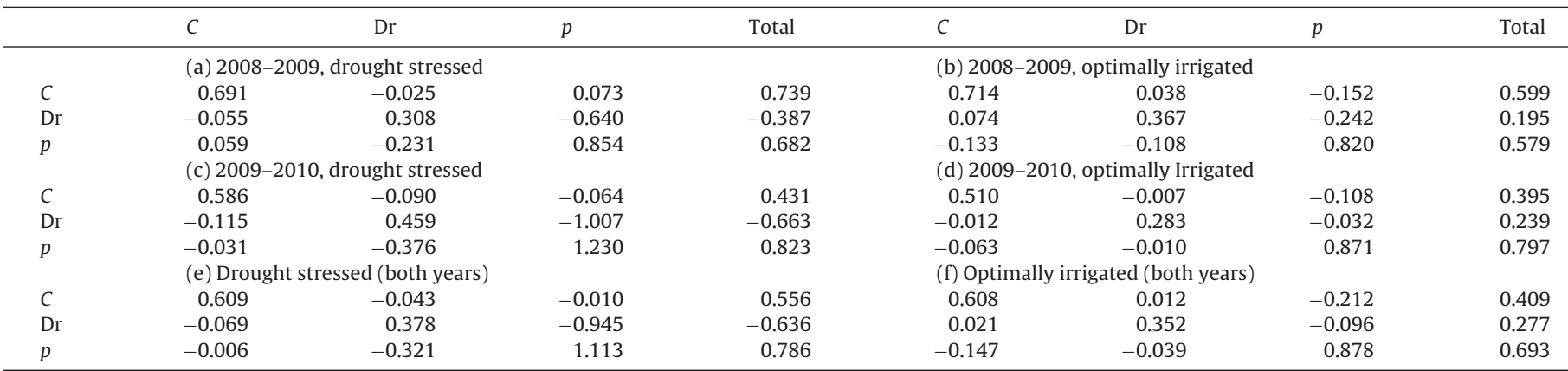

11 and 35\% variation. The regression between yield and $\mathrm{Dr}$ was occasionally negative and significant. It explained 4, 26 and 0\% variation in the desi and 27, 2 and $3 \%$ in the kabuli trials. The regression between yield and $p$ was positive and always significant. It explained 23,51 and $17 \%$ of the variation in the desi and 66 , 54 and $29 \%$ in the kabuli trials. Overall, grain yield variation was largely explained by the variations both in $C$ and $p$ in desi breeding lines, but by $p$ in the kabulis (Fig. 6).

The path coefficients, direct or the total, also showed similar trends of yield explanation as observed in the germplasm. The direct effect of $C$ was moderate but reflected fully on the total effect in all the desi trials. Though there were considerably large direct effects of Dr on yield, this extent was not seen in the total due to a large negative indirect effect through $p$. Similarly the direct effects of $p$ was the largest, but these were largely moderated through the negative indirect effects of Dr. In spite all these interactions the overall direct or total contribution of $C$ was high for desi types and $p$ was high for the kabulis (Table 6).

\subsection{Categorization of the reference collection for $C$ and $p$}

$C$ and $p$ were seen to associate considerably and positively to yield under drought and therefore contrasts for these two traits were sought. As there were significant accession $\times$ year interactions for both $C$ and $p$, the accessions were separated into representative groups using the BLUPs of drought stressed treatment for both $C$
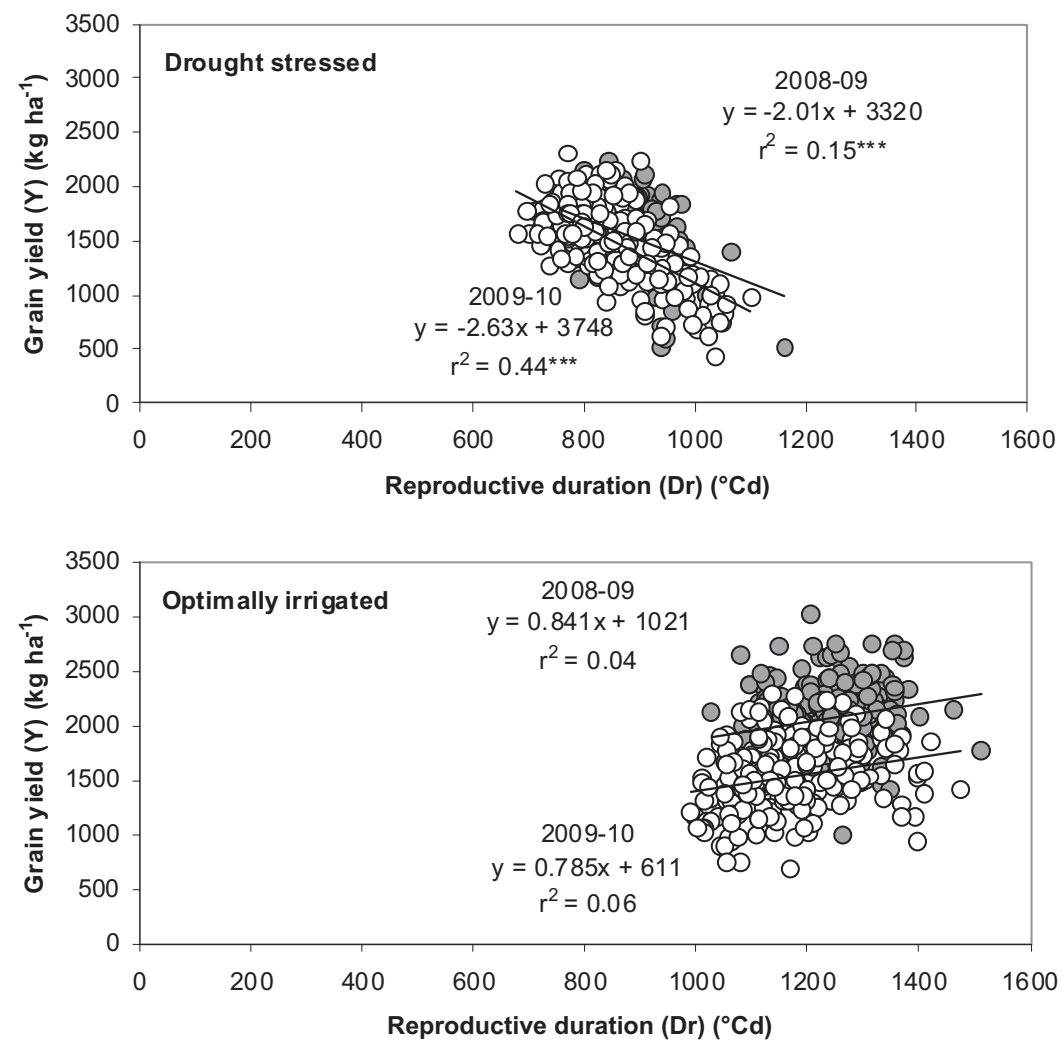

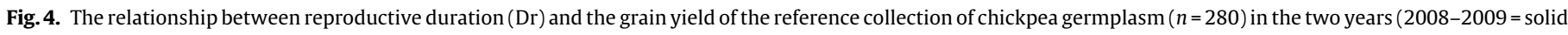
dots and 2009-2010 = open dots) both under drought stressed and optimally irrigated conditions. 

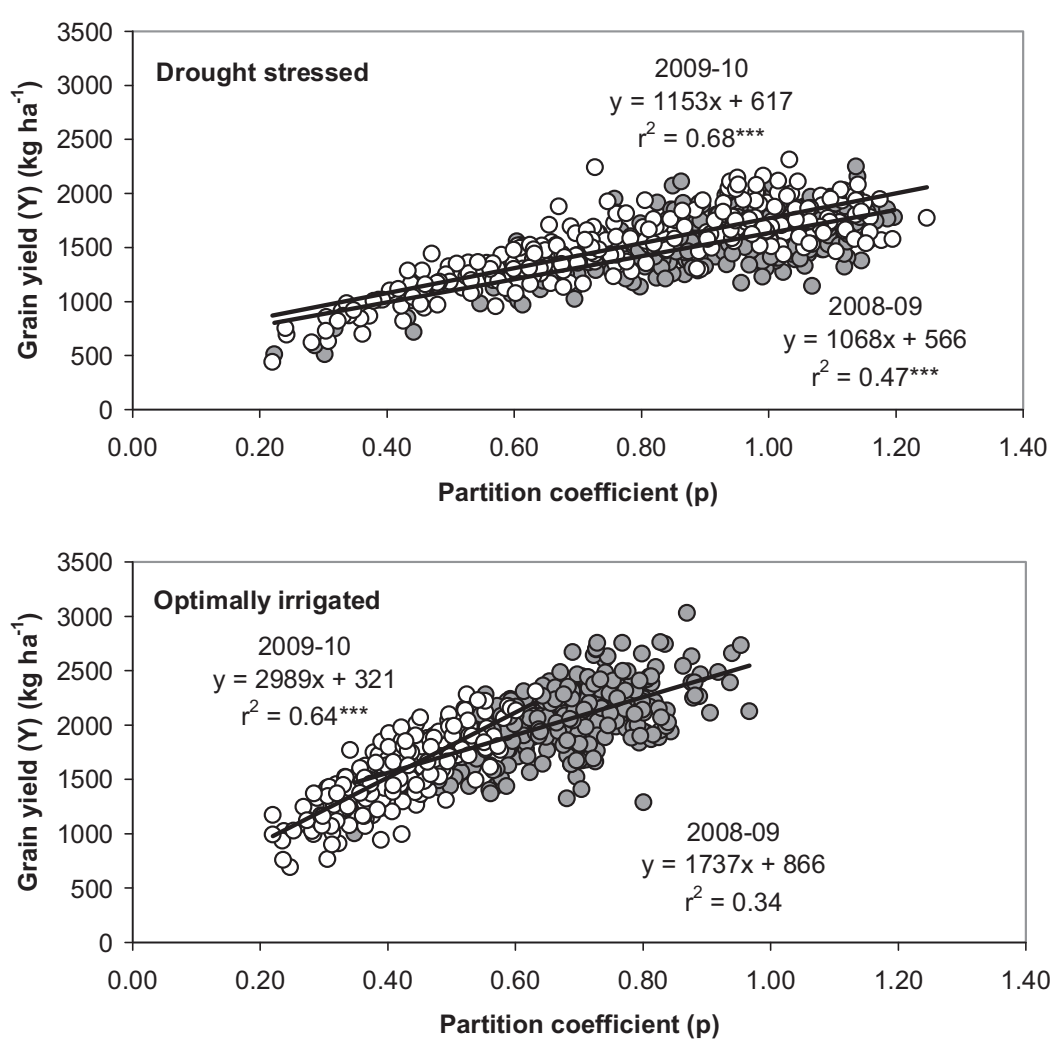

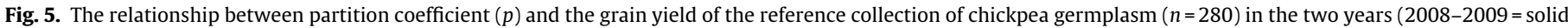
dots and 2009-2010 = open dots) both under drought stressed and optimally irrigated conditions.

and $p$ observed in two years by a hierarchical cluster analysis using Ward's incremental sum of squares method. For the convenience of splitting the whole reference collection into groups of high, moderately high, moderately low and low for the combinations of both $C$ and $p$ ( 16 combinations), a dissimilarity level that yielded 16 clusters with significantly different group means was chosen. Based on the cluster group means, consistently contrasting combinations of $C$ and $p$ are selected as high $C$ and $p$ (with means for 2008-2009; $2009-2010 C=2.15 ; 2.69$ and $p=0.83 ; 0.72$ ), low $C$ and high $p$ (with means $C=1.78 ; 2.12$ and $p=0.93 ; 0.91$ ) and low $C$ and $p$ (with means $C=1.67 ; 2.16$ and $p=0.48 ; 0.35$ ). However there are closely parallel groups that were not presented for the sake of brevity. The first group can be used as parents in short duration environments, second in the long duration environments and the third may find use as lowest checks.

\section{Discussion}

In this work, irrespective of irrigation environment, the variations in crop growth rate and $p$ were found to be associated with grain yield, as also seen in other crops such as common bean (Scully and Wallace, 1990; Scully et al., 1991), groundnut (Jogloy et al., 2011) and winter wheat (White and Wilson, 2006). However, this association improved under drought stress, as shown with advanced breeding lines of chickpea (Krishnamurthy et al., 1999), emphasizing the need for a selection for both these traits. Breeding programs are aware of the need for breeding for crop growth rate or larger final biomass (Singh et al., 1983; White and Wilson, 2006) aiming for higher crop yields through larger plant size. But this is not the case with better $p$. The greatest challenge to using HI directly in breeding programs is its often observed negative linkage with shoot biomass (Scully and Wallace, 1990) and maturity duration (Krishnamurthy et al., 2010). Consequently, HI explains yields poorly as highest yields can result through either increased shoot biomass or increased harvest indices (Austin, 1980; Duncan et al., 1978; Scully and Wallace, 1990; Scully et al., 1991). Direct selection for $\mathrm{HI}$ is rightly deterred as poor harvest indices are often linked to larger plants (well-watered or well-fed or longer duration ones). But this linkage is a result of extended vegetative duration leading to an excessive vegetative growth or conversely reduced reproductive duration. To explain it further, $\mathrm{HI}$ is an integration of two negatively linked individual components, i.e., the reproductive duration and the rate of partitioning (Jogloy et al., 2011; Krishnamurthy et al., 1999). One apparent effect of drought stress is the large reduction in reproductive duration (Fig. 2). Therefore, any effort to keep a higher HI needs to aim for a greater $p$ to compensate for the loss in duration and to keep the yield gap reduced. The importance of and selection for $p$ or HI is not new (Adams, 1982; Duncan et al., 1978; Scully and Wallace, 1990; Jogloy et al., 2011). On the basis of a much earlier hypothesis (Searle, 1965), Scully and Wallace (1990) proposed an equation called Relative Sink Strength (RSS) (equivalent to $p$ here), the ratio of seed growth rate upon biomass growth rate, and suggested 1.0 as the highest sink strength for common beans. In this study, ICC 14778 had a consistent $p$ value of 1.17 and 1.16 , and this genotype is known to be the best for maintaining a cooler canopy temperature (Kashiwagi et al., 2008; Zaman-Allah et al., 2011), known to extract maximum soil water (Zaman-Allah et al., 2011). It performed as a highly drought tolerant genotype in field based yield evaluations (Krishnamurthy et al., 2010). But, selection for best yields often ensures indirect selection for harvest index. If that improved harvest index is a result of increased partitioning duration, this may not be the best adaptation strategy to produce under terminal drought. 
Table 5

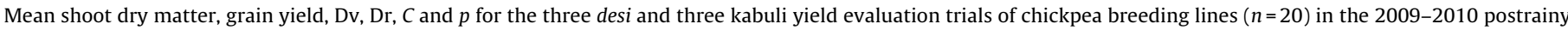
seasons under drought stressed early-sown conditions.

\begin{tabular}{|c|c|c|c|c|c|}
\hline Season/environment & Trial mean & Range of predicted means & S.E. & $\sigma_{\mathrm{g}}^{2}(\mathrm{~S} . \mathrm{E})$. & Heritability $\left(h^{2}\right)$ \\
\hline \multicolumn{6}{|l|}{ Desi trial 1} \\
\hline Shoot dry matter $\left(\mathrm{kg} \mathrm{ha}^{-1}\right)$ & 5091 & $5063-5114$ & 68.2 & $2514(12,499)$ & 0.074 \\
\hline Grain yield $\left(\mathrm{kg} \mathrm{ha}^{-1}\right)$ & 2837 & $2685-2941$ & 105.1 & $10,823(7474)$ & 0.490 \\
\hline $\mathrm{Dv}\left({ }^{\circ} \mathrm{Cd}\right)$ & 1101 & 994-1187 & 28.7 & $3952(1434)$ & 0.896 \\
\hline $\operatorname{Dr}\left({ }^{\circ} \mathrm{Cd}\right)$ & 1093 & 1035-1191 & 29.5 & $2511(990)$ & 0.827 \\
\hline$C\left(\mathrm{~kg} \mathrm{ha}^{-1}{ }^{\circ} \mathrm{Cd}^{-1}\right)$ & 2.81 & $2.74-2.85$ & 0.072 & $0.0035(0.0046)$ & 0.268 \\
\hline$p$ & 0.93 & $0.81-1.01$ & 0.027 & $0.0033(0.0012)$ & 0.890 \\
\hline \multicolumn{6}{|l|}{ Desi trial 2} \\
\hline Shoot dry matter $\left(\mathrm{kg} \mathrm{ha}^{-1}\right)$ & 4788 & $4442-5124$ & 188.5 & $41,726(24,270)$ & 0.574 \\
\hline Grain yield $\left(\mathrm{kg} \mathrm{ha}^{-1}\right)$ & 2819 & $2247-3130$ & 137.6 & $43,394(18,151)$ & 0.782 \\
\hline $\mathrm{Dv}\left({ }^{\circ} \mathrm{Cd}\right)$ & 1107 & 1033-1177 & 27.3 & $1911(775)$ & 0.805 \\
\hline $\operatorname{Dr}\left({ }^{\circ} \mathrm{Cd}\right)$ & 1063 & $1027-1152$ & 19.6 & $1273(488)$ & 0.849 \\
\hline$C\left(\mathrm{~kg} \mathrm{ha}^{-1}{ }^{\circ} \mathrm{Cd}^{-1}\right)$ & 2.67 & $2.44-2.83$ & 0.105 & $0.0136(0.0076)$ & 0.595 \\
\hline$p$ & 0.99 & $0.80-1.10$ & 0.028 & $0.0056(0.0019)$ & 0.929 \\
\hline \multicolumn{6}{|l|}{ Desi trial 3} \\
\hline Shoot dry matter $\left(\mathrm{kg} \mathrm{ha}^{-1}\right)$ & 5132 & $4850-5311$ & 147.2 & $22,370(14605)$ & 0.516 \\
\hline Grain yield $\left(\mathrm{kg} \mathrm{ha}^{-1}\right)$ & 2917 & $2791-3026$ & 105.9 & $9054(8197)$ & 0.381 \\
\hline $\mathrm{Dv}\left({ }^{\circ} \mathrm{Cd}\right)$ & 1147 & 1005-1210 & 28.6 & $3005(1132)$ & 0.864 \\
\hline $\operatorname{Dr}\left({ }^{\circ} \mathrm{Cd}\right)$ & 1060 & 999-1147 & 22.4 & $1702(650)$ & 0.853 \\
\hline$C\left(\mathrm{~kg} \mathrm{ha}^{-1}{ }^{\circ} \mathrm{Cd}^{-1}\right)$ & 2.81 & $2.64-2.91$ & 0.085 & $0.0077(0.0048)$ & 0.533 \\
\hline$p$ & 0.98 & $0.89-1.03$ & 0.036 & $0.0021(0.0010)$ & 0.690 \\
\hline \multicolumn{6}{|l|}{ Kabuli trial 1} \\
\hline Shoot dry matter $\left(\mathrm{kg} \mathrm{ha}^{-1}\right)$ & 4506 & 4155-4908 & 153.7 & $52,625(22,203)$ & 0.775 \\
\hline Grain yield $\left(\mathrm{kg} \mathrm{ha}^{-1}\right)$ & 2202 & 1814-2628 & 117.6 & $43,138(16,741)$ & 0.840 \\
\hline $\mathrm{Dv}\left({ }^{\circ} \mathrm{Cd}\right)$ & 1063 & 953-1151 & 24.2 & $2466(909)$ & 0.882 \\
\hline $\operatorname{Dr}\left({ }^{\circ} \mathrm{Cd}\right)$ & 1255 & 1126-1395 & 27.6 & $5050(1774)$ & 0.925 \\
\hline$C\left(\mathrm{~kg} \mathrm{ha}^{-1}{ }^{\circ} \mathrm{Cd}^{-1}\right)$ & 2.35 & $2.19-2.59$ & 0.074 & $0.0104(0.0046)$ & 0.736 \\
\hline$p$ & 0.75 & $0.54-0.91$ & 0.034 & $0.0099(0.0034)$ & 0.943 \\
\hline \multicolumn{6}{|l|}{ Kabuli trial 2} \\
\hline Shoot dry matter $\left(\mathrm{kg} \mathrm{ha}^{-1}\right)$ & 4633 & $4224-4983$ & 199.1 & $63,640(30,463)$ & 0.689 \\
\hline Grain yield $\left(\mathrm{kg} \mathrm{ha}^{-1}\right)$ & 2238 & $1845-2525$ & 121.8 & $56233(21076)$ & 0.868 \\
\hline $\mathrm{Dv}\left({ }^{\circ} \mathrm{Cd}\right)$ & 1040 & 931-1222 & 15.8 & $4713(1571)$ & 0.973 \\
\hline $\operatorname{Dr}\left({ }^{\circ} \mathrm{Cd}\right)$ & 1264 & $1070-1362$ & 25.0 & $5984(2050)$ & 0.948 \\
\hline$C\left(\mathrm{~kg} \mathrm{ha}^{-1}{ }^{\circ} \mathrm{Cd}^{-1}\right)$ & 2.43 & $2.25-2.57$ & 0.099 & $0.0140(0.0072)$ & 0.646 \\
\hline$p$ & 0.73 & $0.55-0.93$ & 0.034 & $0.0108(0.0037)$ & 0.948 \\
\hline \multicolumn{6}{|l|}{ Kabuli trial 3} \\
\hline Shoot dry matter $\left(\mathrm{kg} \mathrm{ha}^{-1}\right)$ & 4507 & $4182-4904$ & 159.7 & $47,621(22,571)$ & 0.732 \\
\hline Grain yield $\left(\mathrm{kg} \mathrm{ha}^{-1}\right)$ & 2187 & $1985-2446$ & 94.4 & $22,313(9625)$ & 0.800 \\
\hline $\mathrm{Dv}\left({ }^{\circ} \mathrm{Cd}\right)$ & 1046 & $932-1180$ & 17.5 & $5415(1912)$ & 0.972 \\
\hline $\operatorname{Dr}\left({ }^{\circ} \mathrm{Cd}\right)$ & 1254 & 1096-1412 & 21.3 & $9214(3240)$ & 0.975 \\
\hline$C\left(\mathrm{~kg} \mathrm{ha}^{-1}{ }^{\circ} \mathrm{Cd}^{-1}\right)$ & 2.37 & $2.21-2.62$ & 0.083 & $0.0133(0.0062)$ & 0.741 \\
\hline$p$ & 0.74 & $0.64-0.86$ & 0.032 & $0.0056(0.0021)$ & 0.911 \\
\hline
\end{tabular}

Terminal drought reduced Dr more than Dv is an indication that these durations are vulnerable to soil moisture changes. When water is not a limitation for transpiration, canopy and plant temperatures are known to be cooler and close to $25^{\circ} \mathrm{C}$ deviating heavily from the ambient temperatures. Cooler temperatures and shorter photoperiods are known to encourage suppression of reproductive growth (Roberts et al., 1985). As individual or collective effects of soil moisture, temperature and photoperiod are expected to alter both Dv and Dr, making them unstable, genotypes capable of adjusting themselves to such variation and

Table 6

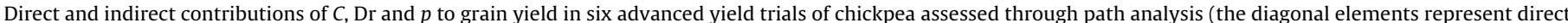
effects, and the off-diagonal elements the indirect effects; the total represents the net effects).

\begin{tabular}{|c|c|c|c|c|c|c|c|c|}
\hline & $C$ & $\mathrm{Dr}$ & $p$ & Total & $C$ & $\mathrm{Dr}$ & $p$ & Total \\
\hline \multicolumn{3}{|c|}{ (a) Desi trial 1} & \multicolumn{6}{|c|}{ (b) Kabuli trial 1} \\
\hline C & 0.761 & -0.073 & 0.058 & 0.746 & 0.517 & 0.036 & -0.159 & 0.394 \\
\hline $\mathrm{Dr}$ & -0.061 & 0.908 & -1.106 & -0.259 & 0.030 & 0.627 & -1.191 & -0.534 \\
\hline$p$ & $\begin{array}{c}0.034 \\
\text { (c) Desi }\end{array}$ & -0.789 & 1.272 & 0.518 & $\begin{array}{l}-0.059 \\
\text { (d) Kab }\end{array}$ & -0.535 & 1.397 & 0.803 \\
\hline$C$ & 0.677 & -0.086 & 0.224 & 0.815 & 0.509 & 0.140 & -0.323 & 0.327 \\
\hline $\mathrm{Dr}$ & -0.140 & 0.419 & -0.819 & -0.540 & 0.123 & 0.578 & -0.899 & -0.197 \\
\hline$p$ & \multicolumn{4}{|c|}{ (e) Desi trial 3} & \multicolumn{4}{|c|}{ (f) Kabuli trial 3} \\
\hline C & 0.795 & -0.032 & -0.092 & 0.671 & 0.745 & -0.100 & -0.058 & 0.587 \\
\hline $\mathrm{Dr}$ & -0.035 & 0.745 & -0.715 & -0.005 & -0.070 & 1.062 & -1.180 & -0.189 \\
\hline$p$ & & \multicolumn{2}{|c|}{ (g) Three desi trials } & 0.449 & \multicolumn{3}{|c|}{ (h) Three kabuli trials } & 0.527 \\
\hline C & 0.786 & -0.015 & -0.149 & 0.652 & 0.575 & 0.052 & -0.218 & 0.409 \\
\hline $\mathrm{Dr}$ & 0.022 & 0.560 & -0.896 & -0.314 & 0.044 & 0.687 & -1.008 & -0.278 \\
\hline$p$ & -0.106 & -0.455 & 1.104 & 0.543 & -0.095 & -0.522 & 1.326 & 0.709 \\
\hline
\end{tabular}



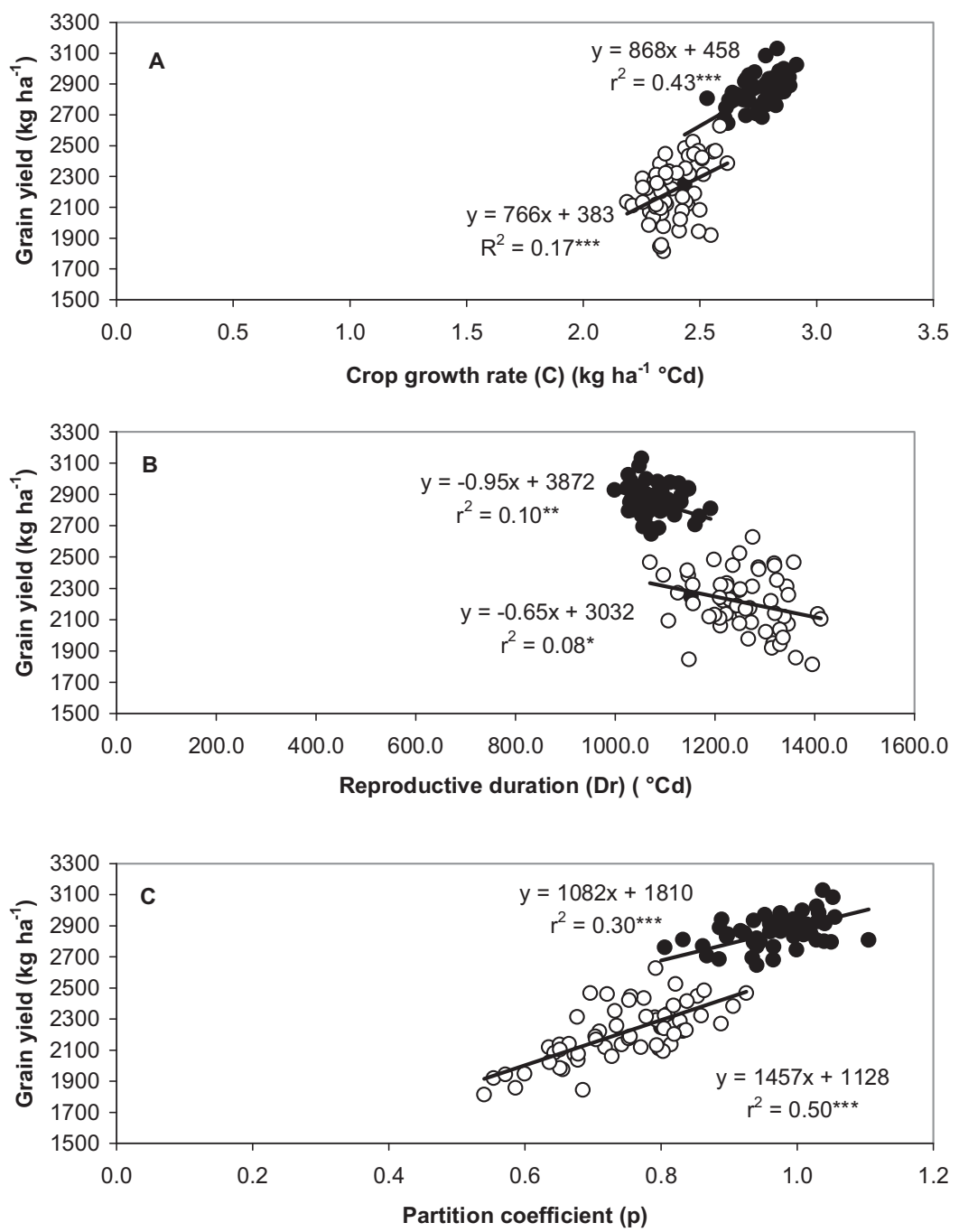

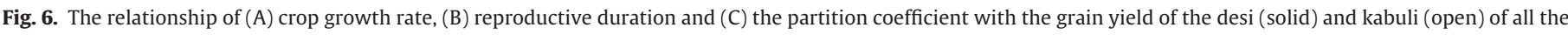
entries of three advanced yield trial of chickpea ( $n=60$ each).

maintain their yield stability are desirable. Selective reduction in reproductive growth phase is commonly observed not only in response to drought stress but also in response to salinity or heat (Krishnamurthy et al., 2010, 2011a,b). And if the efforts to compensate the stress induced yield gaps are to be successful, increased $p$ has to be sought after (Anbessa et al., 2007). The importance of contributory traits increases only when their contribution is greater and stable, but its enhanced use depends on the ease of measurability. Measurement of $p$ is simple and any yield evaluation field trial is sufficient to record the required parameters. It is well known that many interacting traits contribute to drought tolerance with their importance shifting with the level of stress intensity (Tardieu, 2012). The advantage of $p$, as a complex trait, is that it could be improved through many of the traits operating simultaneously. Surprisingly, this trait possesses the best heritability surpassing the estimates for the phenological durations. Selection for this trait is easy and includes a large number of morphological and physiological contributing traits.

Biotic stresses can cause a major reduction in the $p$. Besides biotic stresses, the $p$ can be influenced by several morphological and physiological attributes such as enhanced supply of soil water through a strong root system, non-lodging habit, synchrony in flowering (large number of flowers produced on a single day) twin pods per node and genotypic duration to capture the best temperature regimes at peak grain filling time. The germplasm accessions identified for high $C$ and $p$ (Table 7) also includes genotypes ICC 4958 and ICC 8261, the two top accessions known for their root prolificacy and their use as donor parents for introgressing a stronger root system in drought tolerance breeding (Varshney et al., 2012). It is likely that high levels of $C$ and $p$ become possible through this strong root system supported soil water supply. The drought tolerance of JG 62 that produces two pods at most basal nodes, particularly when exposed to terminal drought (Sheldrake et al., 1978), and of ICC 4958 with its large seeds (Saxena et al., 1993), were recognized as exhibiting a relatively higher sink capacity. Another stable drought tolerant cultivar, ICCV 10 (Johansen et al., 1994), a released cultivar with a wide adaptation (Gowda et al., 1995) seemingly achieves this drought tolerance through synchronous flowering. ICCV 10 grows slowly at the initial stages, but produces large numbers of both basal and terminal branches with flowers appearing on these branches simultaneously. It is also characterized as intermediate in flowering but relatively early in maturity, and this exceptional phenological compromise is identified as being responsible for its wide adaptation (Berger et al., 2006). 
Table 7

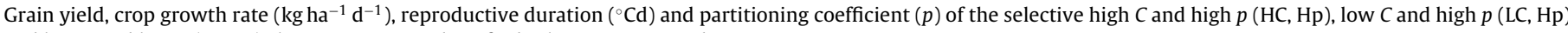
and low $C$ and low $p$ (LC, Lp) cluster group members for both 2008-2009 and 2009-2010 years.

\begin{tabular}{|c|c|c|c|c|c|c|c|c|c|}
\hline \multirow[t]{2}{*}{ Serial No. } & \multirow[t]{2}{*}{ Entries } & \multicolumn{4}{|l|}{ 2008-2009 } & \multicolumn{4}{|l|}{ 2009-2010 } \\
\hline & & Grain yield $\left(\mathrm{kg} \mathrm{ha}^{-1}\right)$ & $C\left(\mathrm{~kg} \mathrm{ha}^{-1} \mathrm{~d}^{-1}\right)$ & $\mathrm{Dr}$ & $p$ & Grain yield $\left(\mathrm{kg} \mathrm{ha}^{-1}\right)$ & $C\left(\mathrm{~kg} \mathrm{ha}^{-1} \mathrm{~d}^{-1}\right)$ & $\mathrm{Dr}$ & $p$ \\
\hline \multicolumn{10}{|c|}{ HC, Hp accessions } \\
\hline 1 & ICC 1392 & 1824 & 1.93 & 902 & 1.07 & 1984 & 2.64 & 808 & 0.93 \\
\hline 2 & ICC 14669 & 1676 & 1.92 & 826 & 1.10 & 2111 & 2.64 & 847 & 0.94 \\
\hline 3 & ICC 15618 & 1552 & 1.91 & 759 & 1.12 & 2038 & 2.67 & 818 & 0.95 \\
\hline 4 & ICC 8384 & 1822 & 1.96 & 849 & 1.13 & 2163 & 2.58 & 855 & 0.99 \\
\hline 5 & ICC 7441 & 1563 & 1.81 & 816 & 1.12 & 2117 & 2.63 & 805 & 1.02 \\
\hline 6 & ICC 15606 & 1790 & 1.95 & 924 & 1.00 & 2147 & 2.69 & 841 & 0.95 \\
\hline 7 & ICC 15762 & 1688 & 1.98 & 862 & 1.00 & 1763 & 2.62 & 800 & 0.85 \\
\hline 8 & ICC 6263 & 1698 & 1.98 & 854 & 1.02 & 2031 & 2.98 & 730 & 0.94 \\
\hline 9 & ICC 10399 & 1808 & 1.98 & 850 & 1.10 & 2314 & 2.96 & 771 & 1.03 \\
\hline 10 & ICC 4958 & 2157 & 2.37 & 801 & 1.14 & 2012 & 2.62 & 793 & 0.98 \\
\hline 11 & ICC 13124 & 2250 & 2.34 & 845 & 1.14 & 2080 & 2.56 & 846 & 0.98 \\
\hline 12 & ICC 14199 & 1907 & 2.31 & 898 & 0.89 & 2049 & 2.85 & 769 & 0.94 \\
\hline 13 & ICC 16654 & 2077 & 2.34 & 870 & 1.01 & 1938 & 2.87 & 815 & 0.81 \\
\hline 14 & ICC 15510 & 2004 & 2.26 & 869 & 1.01 & 1937 & 2.79 & 776 & 0.90 \\
\hline 15 & ICC 15802 & 1878 & 2.17 & 852 & 1.02 & 1841 & 2.77 & 768 & 0.86 \\
\hline \multirow{2}{*}{16} & IG 10309 & 1867 & 2.09 & 869 & 1.04 & 2082 & 2.80 & 786 & 0.95 \\
\hline & Group mean & 1848 & 2.08 & 853 & 1.06 & 2038 & 2.73 & 802 & 0.94 \\
\hline \multicolumn{10}{|c|}{ LC, Hp accessions } \\
\hline 1 & ICC 456 & 1546 & 1.84 & 826 & 1.06 & 1568 & 2.09 & 722 & 1.18 \\
\hline 2 & ICC 14778 & 1745 & 1.90 & 827 & 1.17 & 1641 & 2.10 & 759 & 1.16 \\
\hline 3 & ICC 8607 & 1779 & 1.94 & 835 & 1.14 & 1437 & 2.04 & 766 & 1.02 \\
\hline 4 & ICC 3362 & 1538 & 1.75 & 890 & 1.03 & 1576 & 2.18 & 701 & 1.15 \\
\hline 5 & ICC 10018 & 1568 & 1.83 & 861 & 1.05 & 1651 & 2.20 & 736 & 1.12 \\
\hline 6 & ICC 13892 & 1570 & 1.81 & 820 & 1.12 & 1576 & 2.21 & 679 & 1.19 \\
\hline 7 & ICC 2072 & 1472 & 1.68 & 899 & 1.02 & 1499 & 2.08 & 756 & 1.06 \\
\hline 8 & ICC 4495 & 1442 & 1.66 & 866 & 1.06 & 1729 & 2.14 & 822 & 1.06 \\
\hline 9 & ICC 5434 & 1483 & 1.69 & 858 & 1.09 & 1511 & 2.12 & 767 & 1.02 \\
\hline 10 & ICC 5221 & 1533 & 1.75 & 861 & 1.08 & 1595 & 2.13 & 774 & 1.07 \\
\hline 11 & ICC 8950 & 1577 & 1.75 & 882 & 1.07 & 1598 & 2.18 & 760 & 1.05 \\
\hline 12 & ICC 12866 & 1570 & 1.82 & 792 & 1.16 & 1538 & 2.08 & 769 & 1.06 \\
\hline 13 & ICC 14077 & 1441 & 1.75 & 778 & 1.12 & 1464 & 2.07 & 722 & 1.11 \\
\hline 14 & ICC 15868 & 1510 & 1.72 & 884 & 1.04 & 1538 & 2.04 & 732 & 1.15 \\
\hline 15 & ICC 4639 & 1171 & 1.57 & 823 & 0.96 & 1296 & 1.88 & 853 & 0.89 \\
\hline 16 & ICC 5878 & 1407 & 1.61 & 841 & 1.12 & 1530 & 2.08 & 765 & 1.07 \\
\hline 17 & ICC 12155 & 1330 & 1.55 & 877 & 1.06 & 1512 & 2.09 & 787 & 1.00 \\
\hline \multirow[t]{2}{*}{18} & ICC 5879 & 1320 & 1.46 & 893 & 1.12 & 1572 & 2.06 & 834 & 1.00 \\
\hline & Group mean & 1500 & 1.73 & 851 & 1.08 & 1546 & 2.10 & 761 & 1.08 \\
\hline \multicolumn{10}{|c|}{ LC, Lp accessions } \\
\hline 1 & ICC 1161 & 716 & 1.47 & 937 & 0.44 & 699 & 1.84 & 944 & 0.36 \\
\hline 2 & ICC 8522 & 510 & 1.23 & 937 & 0.30 & 632 & 1.90 & 938 & 0.31 \\
\hline 3 & ICC 11279 & 510 & 1.28 & 1161 & 0.22 & 442 & 1.55 & 1035 & 0.22 \\
\hline 4 & ICC 1915 & 850 & 1.73 & 959 & 0.43 & 867 & 2.12 & 1023 & 0.37 \\
\hline 5 & IG 6154 & 595 & 1.54 & 946 & 0.29 & 729 & 2.11 & 997 & 0.30 \\
\hline 6 & ICC 2242 & 750 & 1.81 & 1049 & 0.32 & 1199 & 2.23 & 927 & 0.58 \\
\hline 7 & ICC 6306 & 1009 & 1.96 & 1026 & 0.44 & 692 & 2.24 & 1002 & 0.24 \\
\hline 8 & ICC 7867 & 1112 & 1.73 & 955 & 0.64 & 986 & 2.33 & 1102 & 0.34 \\
\hline 9 & ICC 9434 & 981 & 1.75 & 931 & 0.55 & 871 & 2.19 & 1036 & 0.34 \\
\hline 10 & IG 6047 & 1128 & 1.81 & 991 & 0.57 & 921 & 2.29 & 1056 & 0.35 \\
\hline 11 & ICC 2720 & 1004 & 1.57 & 1020 & 0.61 & 1360 & 2.36 & 966 & 0.57 \\
\hline 12 & ICC 7305 & 1022 & 1.49 & 979 & 0.69 & 1191 & 2.19 & 925 & 0.58 \\
\hline 13 & ICC 2737 & 1145 & 1.71 & 921 & 0.70 & 1126 & 2.21 & 962 & 0.52 \\
\hline 14 & ICC 8195 & 1173 & 1.70 & 960 & 0.71 & 1100 & 2.14 & 939 & 0.54 \\
\hline 15 & ICC 7052 & 1195 & 1.72 & 951 & 0.69 & 1145 & 2.27 & 1029 & 0.46 \\
\hline 16 & ICC 7323 & 1284 & 1.80 & 916 & 0.75 & 941 & 2.35 & 841 & 0.46 \\
\hline 17 & ICC 3218 & 1138 & 1.65 & 870 & 0.80 & 822 & 2.05 & 911 & 0.43 \\
\hline \multirow[t]{2}{*}{18} & ICC 3239 & 971 & 1.58 & 947 & 0.61 & 842 & 2.07 & 1055 & 0.36 \\
\hline & Group mean & 950 & 1.64 & 970 & 0.54 & 920 & 2.14 & 983 & 0.41 \\
\hline
\end{tabular}

Consideration of a trait for selection and use in breeding depends on its strength of association with yield, its heritability and expression. The heritability of $p$ was particularly high under drought and the repeatability in expression across environments seems good. Though there were significant interaction of accessions $\times$ year was present, the quantum of this was low compared to genotypic variation. Also, the regression of $p$ of genotypes across years explained $70 \%$ of the variation under drought stress and $45 \%$ under optimal irrigation (Fig. 7). A similar association was also seen between drought stressed and optimal irrigated conditions in both the years ( 41 and $46 \%$ ). However, there is an immediate need to assess the $p$ expression in multilocation evaluations to confirm the robustness of $p$. In environments such as wintersown, Mediterranean type and higher latitudes of south Asia where shoot biomass production of chickpea is even more than in tropical environment of Patancheru (Singh et al., 1997; Berger et al., 2004), increased $p$ will be more meaningful even under no stress situation. 

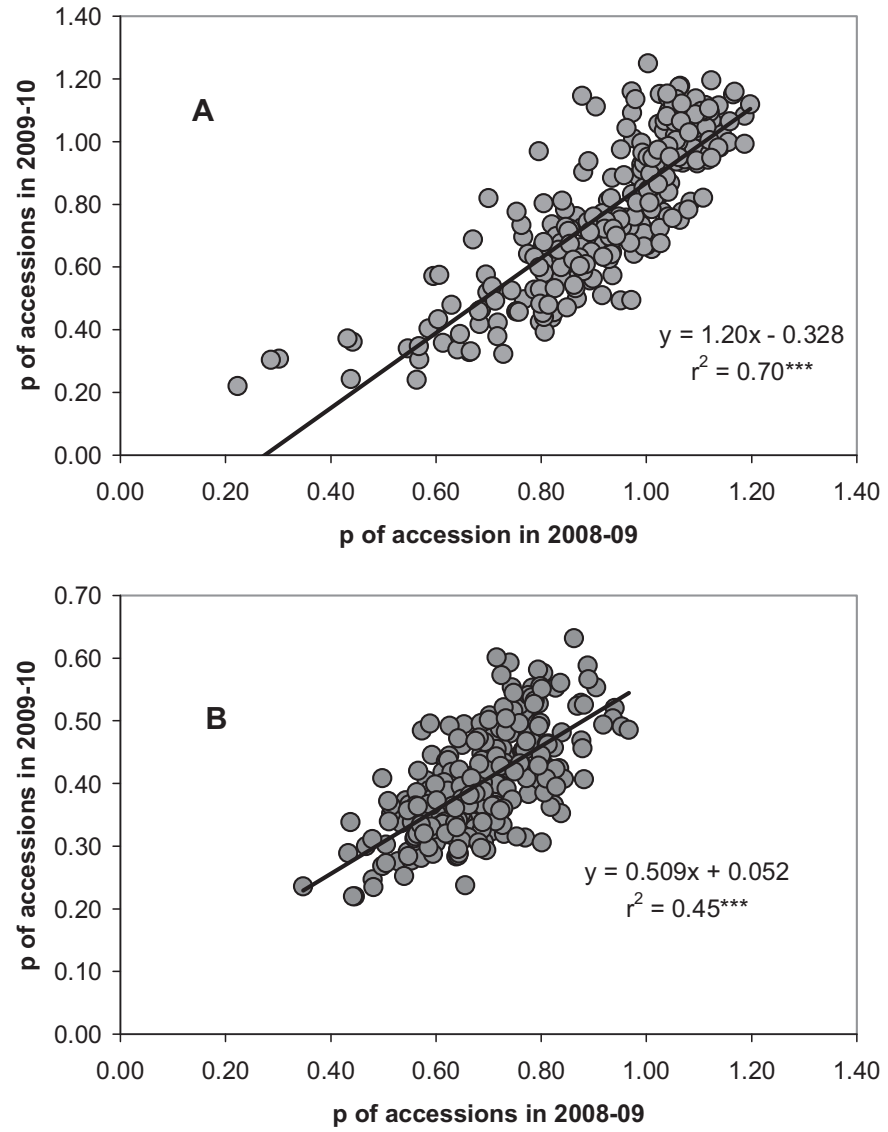

Fig. 7. The relationship of $p$ (partition coefficient) of the germplasm accessions across years of experimentation.

\section{Conclusion}

Both $C$ and $p$ contributed to final yields, but $p$ had a greater contribution particularly under drought meriting selection of this trait in drought tolerance breeding. However, multi-location evaluation is required to confirm the stability and heritability of these yield components. Drought tolerant genotypes that are currently being used for transferring drought tolerance in chickpea are strong sources for $p$ or for both $C$ and $p$. Future drought tolerance breeding programs need to incorporate $p$ for better drought tolerance and yield stability. This method of yield analysis is simple and amenable for high throughput evaluating thousands of germplasm, well beyond the reference collection, for this useful trait.

\section{Acknowledgements}

This work was fully supported by the Bill \& Melinda Gates Foundation through a Generation Challenge Program grant (G4008-12. Linking genetic diversity with phenotype for drought tolerance traits through molecular and physiological characterization of a diverse reference collection of chickpea). The technical support of $\mathrm{Mr}$ J. Shankaraiah in managing the field experiments is gratefully acknowledged.

\section{References}

Adams, M.W., 1982. Plant architecture and yield breeding. Iowa State J. Res. 56, $225-254$.

Anbessa, Y., Warkentin, T., Bueckert, R., Vandenberg, A., YanTai, G., 2007. Postflowering dry matter accumulation and partitioning and timing of crop maturity in chickpea in western Canada. Can. J. Plant Sci. 87, 233-240.
Austin, R.B., 1980. Physiological limitations to cereals yields and ways of reducing them by breeding. In: Hurd, R.G., Biscoe, P.V., Dennis, C. (Eds.), Opportunities for Increasing Crop Yields. Association of Applied Biology/Pitman, London, pp. 3-9.

Bartlett, M.S., 1937. Properties of sufficiency and statistical tests. Proc. Roy. Soc. Lond. A $160,268-282$

Berger, J.D., Ali, M., Basu, P.S., Chaudhary, B.D., Chaturvedi, S.K., Deshmukh, P.S. Dharmaraj, P.S., Dwivedi, S.K., Gangadhar, G.C., Gaur, P.M., Kumar, J., Pannu, R.K., Siddique, K.H.M., Singh, D.N., Singh, D.P., Singh, S.J., Turner, N.C., Yadava, H.S. Yadav, S.S., 2006. Genotype by environment studies demonstrate the critical role of phenology in adaptation of chickpea (Cicer arietinum L.) to high and low yielding environments of India. Field Crop Res. 98, 230-244.

Berger, J.D., Turner, N.C., Siddique, K.H.M., Knights, E.J., Brinsmead, R.B., Mock I., Edmondson, C., Khan, T.N., 2004. Genotype by environment studies across Australia reveal the importance of phenology for chickpea (Cicer arietinum L.) improvement. Aust. J. Agric. Res. 55, 1071-1084.

Chauhan, Y.S., Nene, Y.L., Johansen, C., Haware, M.P., Saxena, N.P., Sardar Singh, Sharma, S.B., Sahrawat, K.L., Burford, J.R., Rupela, O.P., Kumar Rao, J.V.D.K. Sithanantham, S., 1988. Effects of soil solarization on pigeonpea and chickpea. In: Research Bulletin No. 11. International Crops Research Institute for the Semi-Arid Tropics, Patancheru, A.P. 502 324, India, pp. 1-23.

Duncan, W.G., McCloud, D.E., McGraw, R., Boote, K.J., 1978. Physiological aspects of peanut improvement. Crop Sci. 18, 1015-1020.

FAO., 2012. http://faostat.fao.org

Fischer, R.A., 1981. Optimizing the use of water and nitrogen through breeding of crops. Plant Soil. 58, 249-278.

Gallagher, J.N., Biscoe, P.V., Hunter, B., 1976. Effects of drought on grain growth. Nature 264, 541-542.

Gaur, P.M., Srinivasan, S., Thudi, M., Nayak, S., Krishnamurthy, L., Gangarao, N.V.P.R. Kimurto, P., Fikre, A., Jayalakshmi, V., Mannur, D.M., Vijayakumar, A.G., Varshney, R.K., 2013. Drought tolerant and high yielding breeding lines developed through marker-assisted breeding in chickpea. In: Abstract of the paper presented at InterDrought-IV Conference, Perth, Australia, 2-6 September 2013.

Gowda, C.L.L., Singh, O., Sethi, S.C., Singh, K.B., Rao, B.V., Rahman, M.M., Kumar J., Rahman, M.A., 1995. Registration of 'ICCV 10' chickpea. Crop Sci. 35 588.

Hay, R.K.M., 1995. Harvest index: a review of its use in plant breeding and crop physiology. Ann. Appl. Biol. 126, 197-216.

Johansen, C., Krishnamurthy, L., Saxena, N.P., Sethi, S.C., 1994. Genotypic variation in moisture response of chickpea grown under line-source sprinklers in a semiarid tropical environment. Field Crop Res. 37, 103-112.

Jogloy, C., Jaisil, P., Akkasaeng, C., Kesmala, T., Jogloy, S., 2011. Heritability and correlation for components of crop partitioning in advanced generations of peanut crosses. Asian J. Plant Sci. 10, 60-66.

Kashiwagi, J., Krishnamurthy, L., Upadhyaya, H.D., Krishna, H., Chandra, S., Vadez, V., Serraj, R., 2005. Genetic variability of drought-avoidance root traits in the mini-core germplasm collection of chickpea (Cicer arietinum L.). Euphytica 146, 213-222.

Kashiwagi, J., Krishnamurthy, L., Singh, S., Gaur, P.M., Upadhyaya, H.D., Panwar J.D.S., Basu, P.S., Ito, O., Tobita, S., 2006b. Relationships between transpiration efficiency and carbon isotope discrimination in chickpea (Cicer arietinum L.). International Chickpea and Pigeonpea Newsletter 13, 19-21.

Kashiwagi, J., Krishnamurthy, L., Upadhyaya, H.D., Gaur, P.M., 2008. Rapid screening technique for canopy temperature status and its relevance to drought tolerance improvement in chickpea. J. SAT Agric. Res. 6, 1-4.

Krishnamurthy, L., Gaur, P.M., Basu, P.S., Chaturvedi, S.K., Vadez, V., Rathore, A., Varshney, R., Gowda, C.L.L., 2011a. Genetic variation for heat tolerance in the reference collection of chickpea (Cicer arietinum L.) germplasm. PGR 9 , 59-69.

Krishnamurthy, L., Johansen, C., Sethi, S.C., 1999. Investigation of factors determining genotypic differences in seed yield of nonirrigated and irrigated chickpea using a physiological model of yield determination. J. Agron. Crop Sci. 183, 9-17.

Krishnamurthy, L., Kashiwagi, J., Gaur, P.M., Upadhyaya, H.D., Vadez, V., 2010 Sources of tolerance to terminal drought in the chickpea (Cicer arietinum L.) minicore germplasm. Field Crop Res. 119, 322-330.

Krishnamurthy, L., Turner, N.C., Gaur, P.M., Upadhyaya, H.D., Varshney, R.K., Siddique, K.H.M., Vadez, V., 2011b. Consistent variation across soil types in salinity resistance of a diverse range of chickpea (Cicer arietinum L.) genotypes. J. Agron. Crop Sci. 197, 214-227.

Kumar, J., Abbo, S., 2001. Genetics of flowering time in chickpea and its bearing on productivity in semiarid environments. Adv. Agron. 72, 107-138.

Ludlow, M.M., Muchow, R.C., 1990. A critical evaluation of traits for improving crop yields in water-limited environments. Adv. Agron. 43, 107-153.

Nedumaran, S., Bantilan, M.C.S., 2013. Grain legumes futures under changing socioeconomic and climate scenarios. In: ICRISAT Working Paper Series.

Passioura, J.B., 1977. Grain yield, harvest index and water use of wheat. J. Aust. Inst Agric. Sci. 43, 21.

Reynolds, M.P., Trethowan, R.M., 2007. Physiological interventions in breeding for adaptation to abiotic stress. In: Spiertz, J.H.J., Struik, P.C., van Laar, H.H. (Eds.) Scale and Complexity in Plant Systems Research: Gene-Plant-Crop Relations. CIMMYT, Mexico, pp. 129-146.

Roberts, E.H., Hadley, P., Summerfield, R.J., 1985. Effects of temperature and photoperiod on flowering in chickpeas (Cicer arietinum L.). Ann. Bot. 55, 881-892.

Saxena, N.P., Krishnamurthy, L., Johansen, C., 1993. Registration of a drought resistant chickpea germplasm adapted to short duration terminal drought environments. Crop Sci. 33, 1424. 
Scully, B., Wallace, D.H., 1990. The variation and relationship of biomass, growth rates, harvest index and phenology of the yield of common beans. J. Am. Soc. Hort. Sci. 115, 218-225.

Scully, B.T., Wallace, D.H., Viands, D.R., 1991. Heritability and correlation of biomass, growth rates, harvest index and phenology to the yield of common beans. J. Am. Soc. Hort. Sci. 116, 127-130.

Searle, S., 1965. The value of indirect selection: I. Mass selection. Biometrics 21 , $682-702$.

Sheldrake, A.R., Saxena, N.P., Krishnamurthy, L., 1978. The expression and influence on yield of the double-podded character in chickpeas (Cicer arietinum L.). Field Crop Res. 1, 243-253.

Singh, K.B., Reddy, M.V., Malhotra, R.S., 1983. Breeding kabuli chickpeas for high yield, stability and adaptation. In: Saxena, M.C., Varma, S. (Eds.), Faba Beans, Kabuli Chickpeas, and Lentils in the 1980s. ICARDA, Aleppo, Syria, pp. 71-90.

Singh, K.B., Malhotra, R.S., Saxena, M.C., Bejiga, G., 1997. Superiority of winter sowing over traditional spring sowing of chickpea in the Mediterranean region. Agron. J. 89, 112-118.

Singh, P., Virmani, S.M., 1996. Modeling growth and yield of chickpea (Cicer arietinum L.). Field Crop Res. 46, 41-59.

Tardieu, F., 2012. Any trait or trait-related can confer drought tolerance: just design the right drought scenario. J. Exp. Bot. 63, 25-31.

Upadhyaya, H.D., Furman, B.J., Dwivedi, S.L., Udupa, S.M., Gowda, C.L.L., Baum, M Crouch, J.H., Buhariwalla, H.K., Singh, S., 2006. Development of a composite collection for mining germplasm possessing allelic variation for beneficial traits in chickpea. PGR 4, 13-19.

Upadhyaya, H.D., Dwivedi, S.L., Baum, M., Varshney, R.K., Udupa, S.M., Gowda, C.L.L., Hoisington, D., Singh, S., 2008. Genetic structure, diversity, and allelic richness in composite collection and reference set in chickpea (Cicer arietinum L.). BMC Plant Biol. 8, 106.
Varshney, R.K., Kudapa, H., Roorkiwal, M., Thudi, M., Pandey, M.K., Saxena, R.K., Chamarthi, S.K., Mohan, S.M., Mallikarjuna, N., Upadhyaya, H., Gaur, P.M., Krishnamurthy, L., Saxena, K.B., Nigam, S.N., Pande, S., 2012. Advances in genetics and molecular breeding of three legume crops of semi-arid tropics using nextgeneration sequencing and high-throughput genotyping technologies. J. Biosci. 37, 811-820.

Varshney, R.K. Bertoli, D.J. Moretzsohn, M.C. Vadez, V., Krishnamurthy, L, Aruna, R., Nigam, S.N., Moss, B.J., Seetha, K., Ravi, K., He, G., Knapp, S.J., Hoisington, D.A., 2009. The first SSR-based genetic linkage map for cultivated groundnut (Arachis hypogaea L.). Theor. Appl. Genet. 118, 729-739.

Wallace, D.H., Baudoin, J.P., Beaver, J.S., Coyne, D.P., Halseth, D.E., Masaya, P.N. Munger, H.M., Myers, J.R., Silbernagel, M., Yourstone, K.S., Zobel, R.W., 1993 Improving efficiency of breeding for higher crop yield. Theor. Appl. Genet. 86, 27-40.

Wasson, A.P., Richards, R.A., Chatrath, R., Misra, S.C., Sai Prasad, S.V., Rebetzke, G.J., Kirkegaard, J.A., Christopher, J., Watt, M., 2012. Traits and selection strategies to improve root systems and water uptake in water-limited wheat crops. J. Exp. Bot. 63, 3485-3498.

White, E.M., Wilson, F.E.A., 2006. Responses of grain yield, biomass and harvest index and their rates of genetic progress to nitrogen availability in ten winter wheat varieties. Irish J. Agric. Food Sci. 45, 85-101.

Williams, J.H., Saxena, N.P., 1991. The use of non-destructive measurement and physiological models of yield determination to investigate factors determining differences in seed yield between genotypes of 'desi' chickpeas (Cicer arietinum L.). Ann. Appl. Biol. 119, 105-112.

Zaman-Allah, M., Jenkinson, D.M., Vadez, V., 2011. A conservative pattern of water use, rather than deep or profuse rooting, is critical for the terminal drought tolerance of chickpea. J. Exp. Bot. 62, 4239-4252. 